\title{
Metastatic Renal Cell Carcinoma, Clear Cell Type, of the Parotid Gland:
}

\author{
A Case Report, Review of Literature, and \\ Proposed Algorithmic Approach to Salivary \\ Gland Clear Cell Neoplasms in Fine-Needle \\ Aspiration Biopsies
}

\author{
Aaron M. Udager, M.D., Ph.D., ${ }^{1 *}$ and Shilpa A. Rungta, M.D. ${ }^{1,2}$
}

Renal cell carcinoma (RCC), clear cell type, is a commonly encountered metastatic tumor that can present at unusual anatomic sites many years after the primary tumor resection. Noncutaneous metastasis to the parotid gland is unusual; however, a number of cases of parotid RCC metastasis have been reported. Fine-needle aspiration biopsy (FNAB) is regularly utilized during the evaluation of salivary gland lesions, where it has a high sensitivity, specificity, and accuracy; however, the identification and definitive diagnosis of primary and metastatic clear cell neoplasms is a potential diagnostic pitfall for salivary gland FNAB. Here, we describe a case of RCC, clear cell type, metastatic to the parotid gland that was diagnosed entirely from FNAB cell block material, which is the first such reported case to our knowledge. We review the literature for cases of parotid RCC metastasis and focus on the utility of FNAB for synchronous versus metachronous presentations. Finally, we evaluate the differential diagnosis of clear cell parotid lesions, including ancillary histologic studies, and propose an algorithmic approach to clear cell neoplasms of the salivary gland. Diagn. Cytopathol. 2014;42:974-983. (c) 2014 Wiley Periodicals, Inc.

Key Words: calponin; p63; cytokeratin 7 (CK7); periodic acidSchiff (PAS); phosphotungstic acid hematoxylin (PTAH)

${ }^{1}$ Department of Pathology, University of Michigan Health System, Ann Arbor, Michigan

${ }^{2}$ Department of Pathology and Laboratory Medicine, VA Ann Arbor Healthcare System, Ann Arbor, Michigan

*Correspondence to: Aaron M. Udager, M.D., Ph.D., Department of Pathology, University of Michigan Health System, 1301 Catherine Street, Ann Arbor, MI 48109, USA. E-mail: udager@umich.edu

Received 6 May 2013; Revised 26 November 2013; Accepted 9 January 2014

DOI: $10.1002 /$ dc. 23103

Published online 17 February 2014 in Wiley Online Library (wileyonlinelibrary.com).
Renal cell carcinoma (RCC) is the most common primary neoplasm of the kidney and accounts for approximately $2 \%$ of all newly diagnosed cancers in the United States each year. ${ }^{1}$ Several histologic RCC subtypes have been described, including the clear cell type, which comprises up to $70 \%$ of all RCC. RCC, clear cell type, has a known propensity to metastasize, most commonly via direct invasion of the renal veins and vena cava, with subsequent hematogenous dissemination to the lungs; however, unusual metastatic sites or late metachronous metastases $(>10$ years) are not infrequent, and distant metastasis may be the first clinical presentation of the tumor. ${ }^{2}$

RCC metastasis to the head and neck is rare, but more than 30 cases of parotid metastases have been reported over the past 50 years. ${ }^{3-33}$ Metastases account for only $1 \%-4 \%$ of all salivary gland tumors, with the parotid being the most common metastatic site. ${ }^{34}$ The majority of parotid metastases originate from the skin (i.e., melanoma or squamous cell carcinoma), while less than $3 \%$ come from the kidney. Although metastatic renal tumors comprise only approximately $0.1 \%$ of all salivary gland neoplasms, from a pathologist's standpoint, they are important to recognize in order to alert clinicians to a possible occult primary or more diffusely metastatic malignancy.

Fine-needle aspiration biopsy (FNAB) is commonly used to evaluate salivary gland lesions prior to surgical resection, with the main goal being to detect a malignancy or exclude a neoplasm. A subsequent aim is to further classify a lesion as benign, low-grade neoplasm, or high-grade neoplasm, as this distinction is essential in the surgical decision-making process. The sensitivity and specificity of salivary gland FNAB is reportedly as high 
as $98 \%$ for both, with up to $97 \%$ concordance (accuracy) between cytologic and subsequent histologic diagnoses. ${ }^{35}$ Despite its demonstrated utility, there are a number of potential diagnostic pitfalls in the salivary gland FNAB, including the discrimination of primary and metastatic clear cell neoplasms.

Here, we report a case of metastatic RCC, clear cell type, to the parotid gland diagnosed from FNAB cell block material. We then review the literature for cases of parotid RCC metastases, focusing on the usefulness of FNAB. Finally, we consider the differential diagnosis of salivary gland clear cell neoplasms and propose an algorithmic approach to ancillary histologic studies for discriminating between these lesions in FNAB cell block specimens.

\section{Case Report}

\section{Clinical History}

A 64-year-old man with a history of RCC status post left radical nephrectomy 6 years prior presented to his general practitioner for bilateral cerumen removal from his ears and, on physical examination, was found to have a $1.0 \times$ $1.0-\mathrm{cm}$ firm, painless, mobile mass under his right ear. The lesion had been present for several weeks, and the patient denied any symptoms related to the mass (i.e., swelling, erythema, numbness, muscle weakness). He was referred to otolaryngology for evaluation, and a computed tomography (CT) scan of the head and neck demonstrated a $1.4 \times 1.3 \times 1.0-\mathrm{cm}$ soft tissue nodule in the right parotid gland. The patient subsequently underwent FNAB of the right parotid mass.

\section{Right Parotid FNAB}

FNAB was performed with a 24-gauge needle; a portion of the biopsy sample was utilized to produce a SurePath slide, and the remainder of the sample was made into a cell block. The SurePath slide was insufficient for diagnosis, containing numerous neutrophils, eosinophils, and red blood cells with only scant, nondiagnostic squamous and epithelial tissue. Hematoxylin and eosin (H\&E)-stained sections of the cell block specimen revealed small, cohesive clusters of medium-sized, polygonal tumor cells with eosinophilic to clear (vacuolated) cytoplasm, distinct eosinophilic cell borders, and pleomorphic nuclei with vesicular chromatin and variably prominent nucleoli (Fig. 1A). The cytoplasm of malignant cells was magenta in periodic acid-Schiff (PAS)-stained sections and cleared after treatment with diastase (Fig. 1E and F), indicating cytoplasmic glycogen accumulation. Immunohistochemistry was positive for pan-cytokeratin (AE1/AE3/Cam5.2), vimentin, $\mathrm{RCC}$, and $\mathrm{CD} 10$ (focal) (Fig. 1B-D) but negative for cytokeratin 7 (CK7), cytokeratin 20, calponin, and p63 (data not shown); CAIX was strongly positive (Fig. 1G), and thyroid transcription factor 1 (TTF-1) was negative (data not shown).

\section{Review of Prior Left Radical Nephrectomy Specimen}

Given the histologic appearance of the tumor cells in the parotid FNAB cell block specimen, as well as the corresponding immunohistochemical and special staining results, a diagnosis of metastatic clear cell RCC was strongly suggested. Thus, we reviewed the patient's left radical nephrectomy specimen (6 years prior) for histologic correlation. Grossly, a $9.5 \times 6.0 \times 6.0-\mathrm{cm}$ yellowwhite mass was located in the mid to lower pole of the kidney, with focal extension though the renal capsule but without involvement of the renal hilum or vein. Microscopically, the mass consisted of nests of medium-sized polygonal cells with abundant clear cytoplasm, surrounded by a network of thin-walled blood vessels, with pleomorphic nuclei with variably vesicular chromatin and prominent nucleoli (Fig. 1H). There was focal perirenal adipose invasion but no renal vein invasion, and all final surgical margins were negative. Taken together, these findings support a diagnosis of RCC, clear cell type (AJCC pathologic stage T3a). ${ }^{36}$

\section{Follow-Up}

A subsequent CT scan of the chest revealed multiple bilateral pulmonary nodules, consistent with metastatic disease (presumed RCC), and due to the asymptomatic nature of the parotid mass, surgical intervention was deferred. $\mathrm{He}$ was started on sunitinib (previously SU11428), a multitargeted receptor tyrosine kinase inhibitor, and 4 months later, a repeat CT scan of the chest demonstrated interval decrease in the size of the bilateral pulmonary nodules.

\section{Materials and Methods}

The FNAB specimen was placed immediately in CytoRich Red Preservative in a SurePath vial for production of a single SurePath slide by the PrepStain Slide Processor (BD Biosciences, San Jose, CA). The remainder of the cell pellet was resuspended in Histogel (Thermo Fisher Scientific, Waltham, MA) prior to standard processing into formalin-fixed, paraffin-embedded slides. H\&E and PAS staining (with and without diastase digestion) were performed using routine laboratory methods. Immunohistochemistry was performed by the Department of Pathology Immunohistochemistry Laboratory at the University of Michigan using a BenchMark ULTRA automated stainer and the ultraView Universal DAB Detection Kit (Ventana Medical Systems, Oro Valley, AZ). See Table I for details about primary antibodies.

Case reports were identified via a PubMed search with the terms "RCC" or "renal cell carcinoma" and "parotid," and additional case reports were then identified from their 

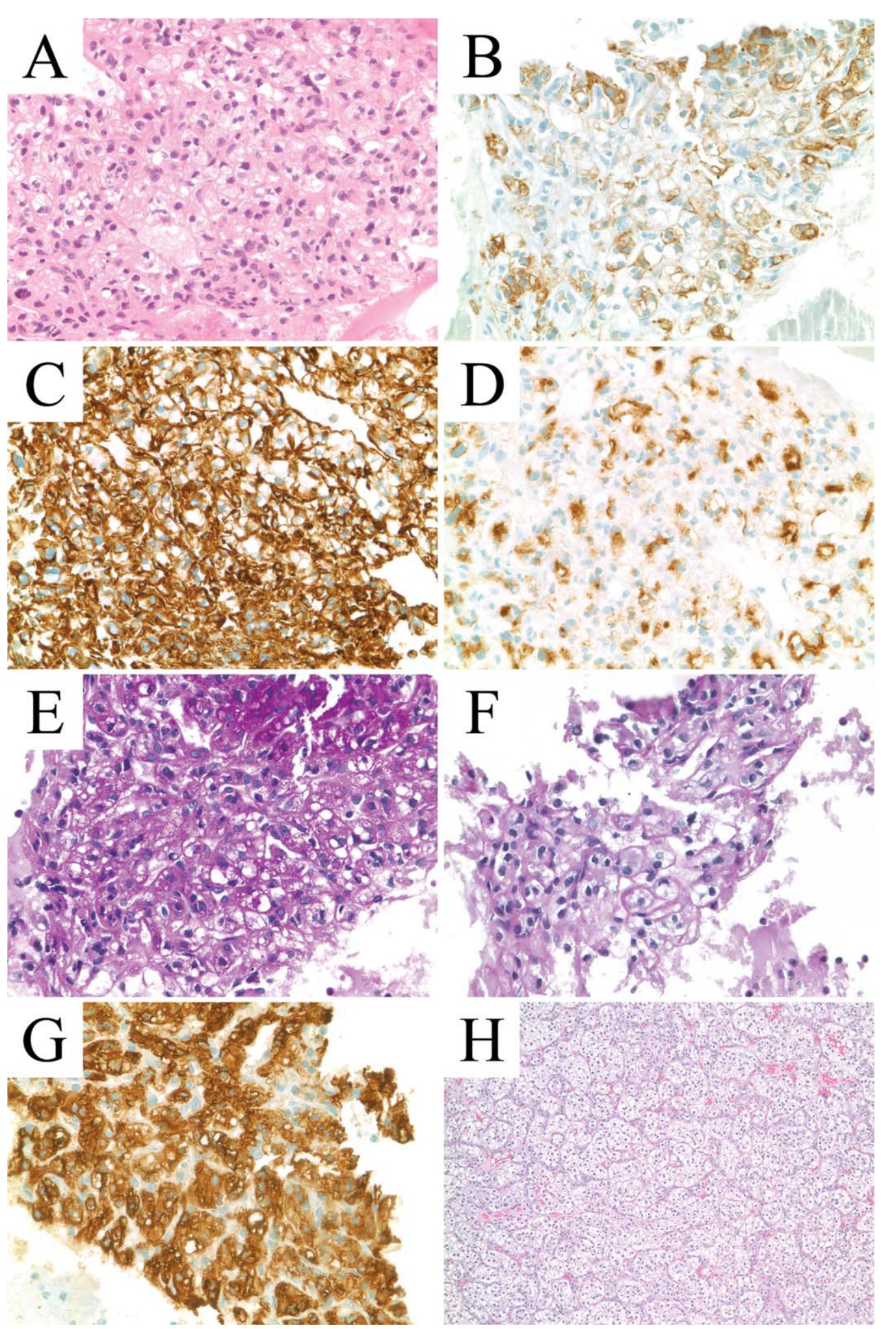

Fig. 1. Metastatic RCC, clear cell type, to the parotid. (A-G) FNAB cell block specimen, $400 \times$ magnification: (A) hematoxylin and eosin (H\&E), (B) pan-cytokeratin, (C) vimentin, (D) RCC, (E) PAS, (F) PAS with diastase, and (G) CAIX. (H) Left radical nephrectomy specimen, H\&E, 100× magnification. [Color figure can be viewed in the online issue, which is available at wileyonlinelibrary.com.] 
Table I. Primary Antibodies

\begin{tabular}{lcl}
\hline Antibody & Concentration & \multicolumn{1}{c}{ Vendor } \\
\hline Calponin & pre-dilute & Cell Marque (Rocklin, CA) \\
Carbonic anhydrase & $1: 600$ & $\begin{array}{l}\text { Novus Biological (Littleton, } \\
\text { CO) }\end{array}$ \\
IX (CAIX) & pre-dilute & Ventana Medical Systems \\
CD10 & $1: 100$ & Cell Marque \\
Cytokeratin 7 (CK7) & $1: 200$ & Cell Marque \\
Cytokeratin 20 & & \\
$\quad$ CK20) & pre-dilute & Ventana Medical Systems \\
p63 & $1: 200 / 1: 40$ & Chemicon/Becton Dickinson \\
Pan-cytokeratin & & \\
[(AE1/AE3)/ & & \\
Cam5.2] & pre-dilute & Ventana Medical Systems \\
RCC & pre-dilute & Cell Marque \\
TTF-1 & pre-dilute & Ventana Medical Systems \\
Vimentin & & \\
\hline
\end{tabular}

bibliographies. Only articles in English were selected, and case reports without sufficient supporting information were excluded. To compare the outcomes of FNAB in reported parotid RCC cases, two-sample hypothesis testing was performed using $2 \times 2$ contingency tables and a two-tailed Fisher's exact test (sum of small $P$ values method).

\section{Discussion}

From the English literature over the past 50 years, we identified an additional 35 reported cases of metastatic RCC to the parotid (Table II). ${ }^{3-33}$ Including our case, the age at diagnosis ranged from 40 to 83 years. It was more common in men than women (22 versus 13 cases, respectively), mirroring the male predominance of RCC more generally. Thirty-two cases involved only 1 side (14 on the right and 18 on the left), while 3 were bilateral, and the maximum tumor dimension ranged from 0.8 to 8.0 $\mathrm{cm}$. Just less than half of the cases presented as synchronous metastases, while 19 cases were discovered metachronously; 1 case presented initially as a synchronous metastasis and then 4 months later metastasized metachronously to the contralateral parotid gland. ${ }^{15}$ The time to metachronous metastasis ranged from 4 months to 19 years, consistent with RCC's known propensity for late metastasis.

In addition to our case, 18 cases had reported FNAB results, including all but 2 in the past 20 years, reflecting the central role for FNAB in screening salivary gland lesions (Table III). ${ }^{17-20,23-33}$ Of these cases, 7 were synchronous metastases, and 12 were metachronous metastases. Interestingly, there was a striking difference in the sensitivity and specificity for FNAB diagnosis of parotid RCC metastasis depending on whether the lesions were synchronous or metachronous. Although nine $(75 \%)$ of the metachronous cases were correctly diagnosed as malignant, only two (29\%) of the synchronous cases were appropriately identified as such $(P=0.074)$. The difference becomes even more pronounced if only the more specific diagnosis of metastatic RCC is considered: although eight $(67 \%)$ of the metachronous metastases were diagnosed correctly, none of the synchronous cases were identified as metastatic RCC $(P=0.013)$. This may simply reflect information bias (i.e., a rare diagnosis is more likely to be made if the possibility of that diagnosis is known to the pathologist); however, the fact that only $11(58 \%)$ of the 19 cases were correctly classified as malignant by FNAB and less than half were identified as metastatic RCC underscores the diagnostic difficulty of such lesions.

Of the eight cases that were not correctly reported as malignant by FNAB, four were nondiagnostic, unsatisfactory, or inconclusive; two were incorrectly diagnosed as pleomorphic adenomas (PAs); and two were thought to be negative (Table III). ${ }^{17,19,24,27-29,31,33}$ Three cases were correctly classified as malignant, but a diagnosis of metastatic RCC was not rendered: the first case showed malignant lymphoma/leukemia in a patient with a history of chronic lymphocytic leukemia (CLL); the second case was incorrectly diagnosed as primary adenocarcinoma of the parotid; and the third case was not further classified (reported as "few malignant cells"). ${ }^{20,23,32}$ These results suggest at least two possible sources of diagnostic difficulty: (1) the adequacy of the FNAB specimen for diagnosis; and (2) the unbiased discrimination of metastatic RCC from other primary or metastatic lesions of the parotid (particular those with clear cell features).

The rate $(21 \%)$ of inadequate or equivocal FNAB specimens in our case report review is higher than the reported frequencies in large salivary gland FNAB cohorts, which can be as low as $3 \% .{ }^{35}$ This likely reflects the range of sampling methods, experience, and ability across different institutions around the world over a period of 20 years, but factors intrinsic to metastatic RCC (i.e., tumor structure) may also contribute. Similar to other case reports, our cytologic specimen was initially nondiagnostic; however, the diagnosis of metastatic RCC was ultimately made based on histopathologic features and ancillary studies of the FNAB cell block specimen. We note that none of the other FNAB cases reported utilizing a cell block in addition to the standard cytologic preparations, and thus to our knowledge, our case is the first to diagnose parotid RCC metastasis from an FNAB cell block specimen.

Because the majority of RCC are clear cell type, the differential diagnosis of parotid RCC metastases includes both primary and metastatic clear cell salivary gland lesions, including (but not limited to) myoepithelialpredominant PA, myoepithelioma, clear cell oncocytoma, clear cell acinic cell carcinoma, myoepithelial carcinoma (MC), epithelial-myoepithelial carcinoma (EMC), mucoepidermoid carcinoma (MEC), primary clear cell carcinoma (otherwise known as hyalinizing clear cell 
UDAGER AND RUNGTA

Table II. Summary of Case Reports

\begin{tabular}{|c|c|c|c|c|c|c|}
\hline Reference & Age (years) & Gender & Location & Size $(\mathrm{cm})^{a}$ & Chronicity & Time to metachronous \\
\hline Patey et al. & 63 & $\mathrm{~F}$ & & & Syn & \\
\hline Kucan et al. & 55 & M & $\mathrm{R}$ & & Syn & \\
\hline Percival and Curt & 71 & $\mathrm{~F}$ & $\mathrm{R}$ & 4 & Syn & \\
\hline Sist et al. & 62 & M & $\mathrm{L}$ & 3 & Syn & \\
\hline Smits and Slootweg & 69 & $\mathrm{~F}$ & $\mathrm{R}$ & 2 & Meta & 9 years \\
\hline Hessan et al. & 52 & M & $\mathrm{L}$ & & Syn & \\
\hline Harrison et al. & 60 & $\mathrm{~F}$ & $\mathrm{R}$ & $2 / 2 / 2$ & Meta & $10 / 14$ years \\
\hline Günbay et al. & 60 & M & $\mathrm{L}$ & 4 & Meta & 19 months \\
\hline Melnick et al. & 72 & M & $\mathrm{L}$ & 8 & Syn & \\
\hline Owens et al. & 75 & $\mathrm{~F}$ & $\mathrm{~L}$ & 3 & Meta & 8 years \\
\hline Owens et al. & 55 & M & $\mathrm{R}$ & 4 & Syn & \\
\hline Coppa and Oszczakiewicz & 42 & M & $\mathrm{L}$ & 4 & Syn & \\
\hline Pisani et al. & 59 & M & $\mathrm{L}$ & 2 & Syn & \\
\hline Sarangi and Hameed & 71 & M & $\mathrm{B}$ & & Syn/Meta & 4 months \\
\hline Ravi et al. & 55 & $\mathrm{~F}$ & $\mathrm{~B}$ & 3 & Meta & 7 years \\
\hline Borghi et al. & 63 & M & $\mathrm{R}$ & 2.5 & Syn & \\
\hline Stanley et al. & 71 & $\mathrm{~F}$ & $\mathrm{R}$ & & Meta & \\
\hline Stanley et al. & 40 & M & $\mathrm{R}$ & & Meta & \\
\hline Sykes et al. & 59 & & $\mathrm{~L}$ & 3 & Syn & \\
\hline Gangopadhyay et al. & 48 & M & $\mathrm{L}$ & 1.5 & Syn & \\
\hline Vara et al. & 55 & M & $\mathrm{L}$ & 2 & Meta & $5 / 6$ years \\
\hline Adil et al. & 52 & M & $\mathrm{R}$ & 6 & Meta & 5 months \\
\hline Kundu et al. & 61 & M & $\mathrm{R}$ & 2 & Syn & \\
\hline Li et al. & 63 & M & $\mathrm{B}$ & $3 / 2.5$ & Meta & $10 / 14$ years \\
\hline Park and Hlivkio & 83 & $\mathrm{~F}$ & $\mathrm{~L}$ & 2.5 & Meta & 10 years \\
\hline Gögüüs et al. & 59 & $\mathrm{~F}$ & $\mathrm{R}$ & 3 & Meta & 10 years \\
\hline Seijas et al. & 67 & M & $\mathrm{L}$ & 2 & Syn & \\
\hline Newton et al. & 74 & $\mathrm{~F}$ & $\mathrm{R}$ & 1.5 & Meta & 7 years \\
\hline Mrena et al. & 76 & $\mathrm{~F}$ & $\mathrm{R}$ & & Meta & 9 years \\
\hline Mrena et al. & 62 & M & $\mathrm{L}$ & 3 & Meta & 5 years \\
\hline Mrena et al. & 58 & $\mathrm{~F}$ & $\mathrm{R}$ & 0.8 & Syn & \\
\hline Spreafico et al, & 67 & M & $\mathrm{R}$ & 6 & Meta & 18 months \\
\hline Laco et al. & 75 & M & $\mathrm{R}$ & 3 & Syn & \\
\hline Deeb et al. & 82 & M & $\mathrm{R}$ & 4 & Meta & 19 years \\
\hline Lau et al. & 79 & $\mathrm{~F}$ & $\mathrm{~L}$ & 2 & Meta & 16 years \\
\hline \multirow[t]{2}{*}{ Udager and Rungta } & 64 & $\mathrm{M}$ & $\mathrm{R}$ & 1.4 & Meta & 6 years \\
\hline & $(40-83)$ & $(22 \mathrm{M}, 13 \mathrm{~F})$ & (14 L, $18 \mathrm{R}, 3 \mathrm{~B})$ & $(0.8-8.0)$ & $(17 \mathrm{~S}, 20 \mathrm{M})$ & (4 months-19 years) \\
\hline
\end{tabular}

M, male; F, female; R, right; L, left; B, bilateral; Syn, synchronous; Meta, metachronous.

${ }^{\mathrm{a}}$ Maximum dimension.

carcinoma), clear cell thyroid carcinoma, and melanoma. The cytologic and histologic characteristics of these lesions are described in detail elsewhere ${ }^{34,37,38}$; however, we briefly highlight the salient cytomorphologic features of these tumors here. In cytology preparations, PA is often recognized by its biphasic population of duct epithelial and myoepithelial cells and mesenchymal-like stroma. Duct epithelial cells are medium-sized and round to cuboidal, with small round nuclei and nucleoli, finely granular chromatin, eosinophilic cytoplasm, and welldefined cell borders. Myoepithelial cells, on the other hand, show considerable cytomorphologic variability, ranging in size from small to large with pleomorphic cellular and nuclear features. Duct epithelial cells are often tightly cohesive and form small tubules, while myoepithelial cells are usually more loosely cohesive and can be found either in small fascicles or as individual cells. The other major component of PA-the mesenchymal-like stroma-also demonstrates substantial variability, ranging from paucicellular to hypercellular with myxoid, chon- droid, or collagenous elements; in Papanicolaou-stained smears, the stroma usually appears pale or eosinophilic, while in Romanowsky-stained cytologic specimens, it has a purple appearance.

Myoepithelial cells are a common feature of PA, myoepithelioma, MC, and EMC. In some PA, the duct epithelial cell population is only a minor component, and such myoepithelial-predominant PA can be difficult to distinguish from myoepithelioma; although not strictly diagnostic, the presence of mesenchymal-like stroma suggests a diagnosis of PA. MC and EMC have similar overall cytomorphologies to myoepithelioma and PA, respectively, but there is marked nuclear pleomorphism and, commonly, mitoses and intranuclear inclusions ("pseudonucleoli"); these features should be sufficiently worrisome as to warrant the consideration of a malignant lesion (Fig. 2G and $\mathrm{H}$ ).

Cytologic samples from oncocytoma are usually very cellular, containing sheets or trabeculae of large, polygonal cells with granular cytoplasm, well-defined cell 
Table III. Summary of Case Report FNAB Results

\begin{tabular}{|c|c|c|c|}
\hline \multirow[b]{2}{*}{ Reference } & \multicolumn{2}{|c|}{ Diagnostic } & \multirow[b]{2}{*}{ Details } \\
\hline & Malignant & $R C C$ & \\
\hline \multicolumn{4}{|l|}{ Synchronous } \\
\hline Borghi et al. & $\mathrm{N}$ & $\mathrm{N}$ & $\begin{array}{l}\text { Unsatisfactory for } \\
\text { diagnosis }\end{array}$ \\
\hline Sykes et al. & $\mathrm{N}$ & $\mathrm{N}$ & Negative \\
\hline Gangopadhyay et al. & $\mathrm{Y}$ & $\mathrm{N}$ & Few malignant cells \\
\hline Kundu et al. & $\mathrm{Y}$ & $\mathrm{N}$ & $\begin{array}{l}\text { Adenocarcinoma of } \\
\text { the parotid }\end{array}$ \\
\hline Seijas et al. & $\mathrm{N}$ & $\mathrm{N}$ & $\begin{array}{l}\text { No evidence of } \\
\text { malignancy }\end{array}$ \\
\hline Mrena et al. & $\mathrm{N}$ & $\mathrm{N}$ & Pleomorphic adenoma \\
\hline Laco et al. & $\begin{array}{c}\mathrm{N} \\
(2 \mathrm{Y}, \\
5 \mathrm{~N})\end{array}$ & $\begin{array}{c}\mathrm{N} \\
(0 \mathrm{Y}, \\
7 \mathrm{~N})\end{array}$ & Nondiagnostic \\
\hline \multicolumn{4}{|l|}{ Metachronous } \\
\hline Stanley et al. & $\mathrm{Y}$ & $\mathrm{Y}$ & \\
\hline Stanley et al. & $\mathrm{Y}$ & $\mathrm{Y}$ & \\
\hline Li et al. & $\mathrm{N}$ & $\mathrm{N}$ & Pleomorphic adenoma \\
\hline Park and Hlivkio & Y & $\mathrm{Y}$ & \\
\hline Gögüş et al. & $\mathrm{Y}$ & $\mathrm{Y}$ & \\
\hline Newton et al. & $\mathrm{N}$ & $\mathrm{N}$ & Inconclusive \\
\hline Mrena et al. & $\mathrm{Y}$ & $\mathrm{Y}$ & \\
\hline Mrena et al. & $\mathrm{Y}$ & $\mathrm{Y}$ & \\
\hline Spreafico et al. & $\mathrm{Y}$ & $\mathrm{Y}$ & \\
\hline Deeb et al. & $\mathrm{Y}$ & $\mathrm{N}$ & $\begin{array}{l}\text { Malignant lymphoma/ } \\
\text { leukemia }\end{array}$ \\
\hline Lau et al. & $\mathrm{N}$ & $\mathrm{N}$ & Inconclusive \\
\hline Udager and Rungta & $\begin{array}{c}\mathrm{Y} \\
(9 \mathrm{Y}, 3 \mathrm{~N})\end{array}$ & $\begin{array}{c}\mathrm{Y} \\
(8 \mathrm{Y}, 4 \mathrm{~N})\end{array}$ & \\
\hline
\end{tabular}

${ }^{\text {a }}$ Patient had a history of CLL.

borders, small, round, centrally placed nuclei, and prominent, cherry-red nucleoli. Well-differentiated acinic cell carcinoma can have a similar appearance to oncocytoma; however, acinic cell carcinoma lacks a prominent nucleolus and typically forms loosely cohesive acinar-like clusters (as opposed to sheets or trabeculae) (Fig. 2E). Acinic cell carcinoma may be associated with dense lymphoid infiltrates containing prominent germinal centers, but mitoses and necrosis are uncommon features.

MEC has a diverse cytomorphology and consists of at least four different types of malignant cells-mucinproducing (goblet) cells, intermediate cells, squamous (epidermoid) cells, and clear cells-the relative distribution of which varies with the tumor's histologic grade. Mucus-producing cells are medium to large with eccentric nuclei and vacuolated cytoplasm. Intermediate cells vary from small, basaloid-type to medium-sized, cuboidal-type and demonstrate varying degrees of pleomorphism depending on the histologic grade of the MEC. Squamous cells have the appearance of mature squamous epithelial cells. Clear cells are large, round cells with clear cytoplasm and small nuclei and nucleoli. Low-grade MEC is often a paucicellular, polymorphic lesion, with a predominance of mucus-producing cells, variable numbers of clear cells, and relatively few intermediate and squamous cells; these features are nonspecific and can be difficult to differentiate from a benign lesion, such as mucocele. Intermediate-grade MEC is more cellular than its lowgrade counterpart and consists predominantly of intermediate and squamous cells (Fig. 2F); mucus-producing cells are often seen as well, but clear cells are rare. High-grade MEC is composed almost entirely of loosely cohesive, pleomorphic cells, with focal areas of mucus-producing and intermediate cells; the presence of these cell types in a high-grade salivary gland lesion suggests the diagnosis of MEC.

Clear cell thyroid carcinoma is a described variant of papillary thyroid carcinoma (PTC); in cytologic specimens, PTC cells are medium sized with characteristic nuclear features, including molding and/or crowding, grooves, pseudoinclusions, "powdery" chromatin, and prominent nucleoli. The cytomorphology of melanoma, on the other hand, is considerably variable but often demonstrates poorly cohesive clusters of large, pleomorphic, binucleated cells with eccentric nuclei and prominent nucleoli (Fig. 2C and D). Although the presence of melanin pigment (in combination with the aforementioned cytologic features) suggests a diagnosis of melanoma, approximately half of all melanomas are amelanotic; thus, lack of melanin pigment does not exclude melanoma.

Finally, cytologic specimens from RCC, clear cell type, are often very bloody and can range from paucicellular to hypercellular. Tumor cells are usually large with irregular, indistinct cell borders, abundant clear or finely granular cytoplasm, small- to medium-sized eccentric nuclei, and variably prominent nucleoli (depending on grade) (Fig. 2A and B). On Romanowsky staining, pink, strandlike fibrillary material is often seen and, when present, is highly suggestive of a diagnosis of RCC.

In cases for which definitive tumor classification cannot be made by standard cytologic and/or routine $H \& E$ cell block specimen, ancillary studies may help to distinguish between these entities (Table IV). ${ }^{34,39-46}$ On the basis of these staining characteristics, we propose an algorithmic approach to clear cell lesions of the salivary gland using a limited set of immunohistochemical stains: pancytokeratin, vimentin, calponin, and p63 (Fig. 3). Because parotid metastases are overwhelmingly of cutaneous origin, melanoma should be a consideration in an otherwise unspecified clear cell salivary gland lesion; a pancytokeratin cocktail immunohistochemistry (e.g., AE1/ AE3/Cam5.2) will help to exclude melanoma (negative). For lesions that are pan-cytokeratin positive, vimentin immunohistochemistry will help separate acinic cell carcinoma, clear cell carcinoma, and MEC (negative) from other neoplasms. For these tumors, p63 immunohistochemistry differentiates primary clear cell carcinoma (positive) and MEC (positive in epidermoid cells) from acinic cell carcinoma (negative). However, because oncocytomas are positive for p63 and variably negative for 


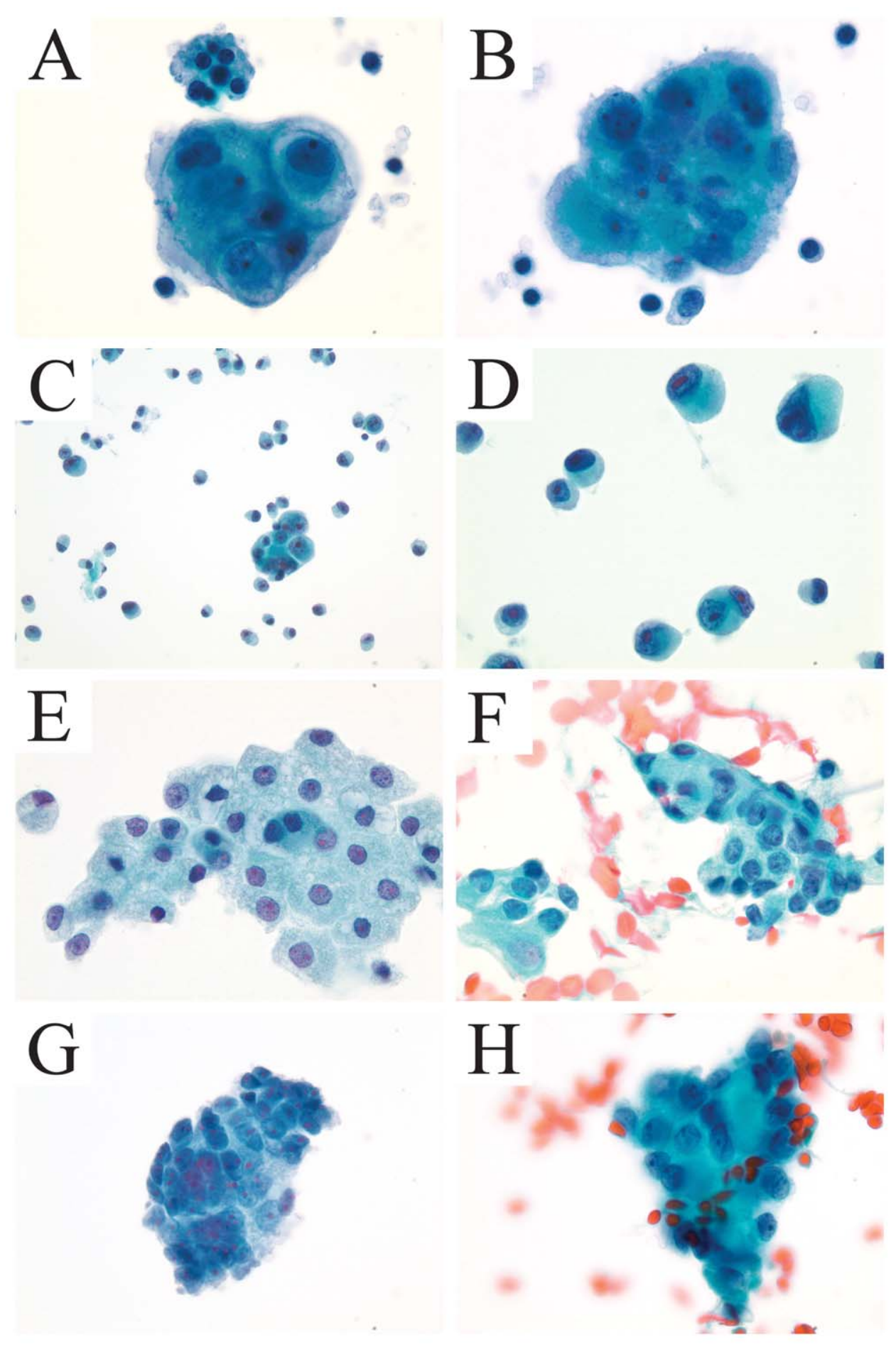

Fig. 2. Cytomorphologic features in the differential diagnosis of clear cell salivary gland lesions. (A and $\mathbf{B})$ ThinPrep specimen of pleural fluid showing metastatic RCC, clear cell type, 1000× magnification. Tumor cells are large and arranged in small, cohesive clusters; they have clear to finely granular, "bubbly" cytoplasm with large nucleoli and conspicuous nucleoli. (C and D) ThinPrep specimen of a parotid mass FNAB showing metastatic melanoma, $400 \times$ and $1000 \times$ magnification. Tumor cells are predominantly in a single-cell pattern with occasional small, poorly cohesive clusters (C); there is considerable pleomorphism, but many of the tumor cells have a plasmacytoid appearance with large nuclei (and/or binucleation) and prominent nucleoli (D). (E) ThinPrep specimen of a parotid mass FNAB showing low-grade acinic cell carcinoma, 1000× magnification. The specimen is hypercellular with numerous cohesive clusters of medium-sized, polygonal tumor cells; these cells have finely granular and/or vacuolated cytoplasm and medium-sized nuclei with irregular nuclear membranes and variably prominent nucleoli. (F) An air-dried, Papanicolaou-stained smear of a parotid mass FNAB showing an intermediate-grade mucoepidermoid carcinoma. The specimen is paucicellular with rare, small, cohesive clusters of mediumsized tumor cells; these intermediate-type cells have variable amounts of finely granular cytoplasm and medium-sized nuclei without prominent nucleoli. Other areas of the slide showed abundant background mucin. ( $\mathbf{G}$ and $\mathbf{H})$ ThinPrep specimen and air-dried, Papanicolaou-stained smear, respectively, of a parotid mass FNAB showing myoepithelial carcinoma. Tumor cells are predominantly arranged in small, cohesive clusters and finely granular cytoplasm, pleomorphic nuclei with nuclear crowding $(\mathrm{G})$ and irregular nuclear membranes $(\mathrm{H})$, and conspicuous nucleoli. [Color figure can be viewed in the online issue, which is available at wileyonlinelibrary.com.] 
Table IV. Immunohistochemistry and Special Staining of Clear Cell Salivary Gland Lesions

\begin{tabular}{|c|c|c|c|c|c|c|c|c|c|c|}
\hline & Location & $\begin{array}{c}\text { Pan- } \\
\text { cytokeration }\end{array}$ & $\begin{array}{l}H M B- \\
45\end{array}$ & Vimentin & Calponin & p63 & $C K 7$ & CK20 & $P A S-D$ & $\begin{array}{l}\text { Other positive } \\
\text { stains }\end{array}$ \\
\hline \multicolumn{11}{|l|}{ Benign (primary) } \\
\hline Pleomorphic adenoma & Parotid & + & & + & + & + & + & - & Sensitive & \\
\hline Myoepithelioma & Parotid & + & & + & + & + & + & - & Sensitive & \\
\hline Oncocytoma & Parotid & + & & $+1-$ & - & + & + & - & Sensitive & PTAH \\
\hline \multicolumn{11}{|l|}{ Malignant (primary) } \\
\hline Acinic cell carcinoma & Parotid & + & & - & - & - & + & - & Resistant & PR, PSA, DOG1 \\
\hline Myoepithelial carcinoma & Parotid & + & & + & + & + & + & - & Sensitive & \\
\hline $\begin{array}{l}\text { Epithelial-myoepithelial } \\
\text { carcinoma }\end{array}$ & Parotid & + & & + & + & + & $+^{\mathrm{a}}$ & - & Sensitive & \\
\hline $\begin{array}{l}\text { Mucoepidermoid } \\
\text { carcinoma }\end{array}$ & Parotid & + & & - & - & $+^{\mathrm{b}}$ & + & - & Sensitive & $\begin{array}{l}\text { Mucin } \\
\quad \text { (i.e., mucicarmine) }\end{array}$ \\
\hline Clear cell carcinoma & $\begin{array}{l}\text { Intraoral } \\
\text { minor } \\
\text { salivary } \\
\text { glands }\end{array}$ & + & & - & - & + & + & - & Sensitive & CEA, EMA \\
\hline \multicolumn{11}{|l|}{ Metastases } \\
\hline Renal cell carcinoma & & + & & + & & - & - & - & Sensitive & $\begin{array}{l}\text { EMA, CD10, } \\
\text { RCC, Pax2, Pax8 }\end{array}$ \\
\hline Thyroid carcinoma & & + & & + & & - & + & - & Sensitive & $\begin{array}{l}\text { TTF-1, thyroglobulin, } \\
\text { Pax2, Pax8 }\end{array}$ \\
\hline Melanoma & & - & + & & & & & & & $\begin{array}{l}\text { Melan-A, MITF, } \\
\text { tyrosinase, S-100 }\end{array}$ \\
\hline
\end{tabular}

Assembled from Refs.:34, 38-45.

${ }^{\mathrm{a}} \mathrm{CK} 7$ staining in epithelial cells.

${ }^{\mathrm{b}}$ 63 staining in squamoid cells.

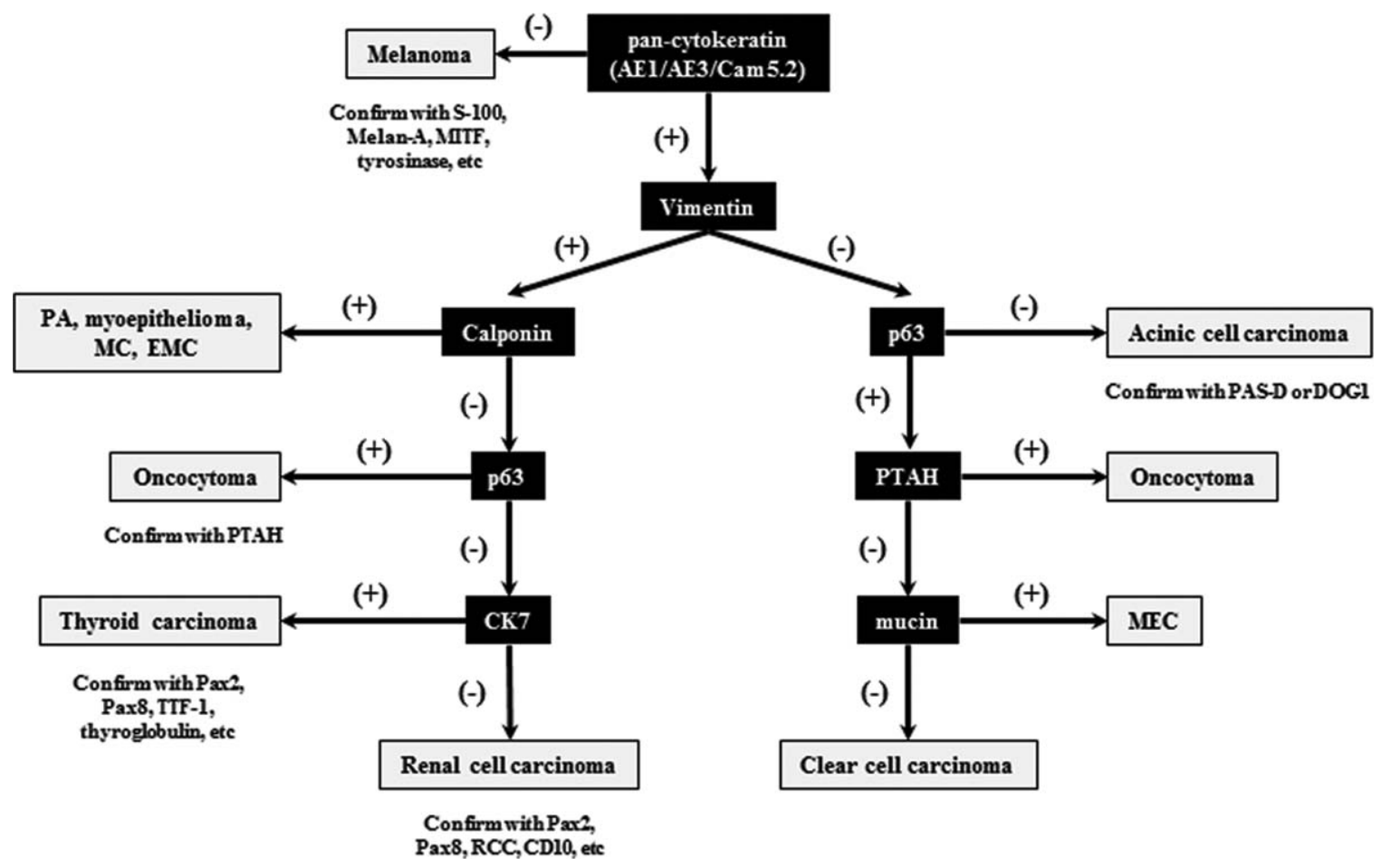

Fig. 3. Proposed algorithmic approach to clear cell salivary gland lesions. Black boxes correspond to immunohistochemical or special stains. PTAH, phosphotungstic acid hematoxylin; (+), positive; (-), negative; PA, pleomorphic adenoma; MC, myoepithelial carcinoma; EMC, epithelial-myoepithelial carcinoma; MEC, mucoepidermoid carcinoma.

vimentin, phosphotungstic acid hematoxylin will help separate MEC and clear cell carcinoma (negative) from oncocytoma (positive). Finally, mucin stains (i.e., muci- carmine) will help distinguish between MEC (positive in mucus-producing cells) and clear cell carcinoma (negative). 
For vimentin-positive, pan-cytokeratin-positive lesions, calponin will help differentiate myoepithelial tumors (positive) from metastatic clear cell carcinomas (negative). In addition, p63 immunohistochemistry helps separate vimentin-positive oncocytomas (positive) from metastatic clear cell carcinomas (negative). It should be noted, however, that p63 is also a marker of myoepithelial differentiation. Thus, in cases where calponin is negative but p63 is positive, it is important to still consider the possibility of a myoepithelial lesion; immunohistochemical confirmation with a third myoepithelial marker (i.e., alpha smooth muscle actin) and/or correlation with the cytomorphology are essential. Finally, CK7 immunohistochemistry will help localize potential metastatic clear cell carcinomas, with most thyroid carcinomas positive and most RCC negative. Initial algorithmic stratifications should be followed by with confirmatory immunohistochemical and/or special staining where appropriate (Fig. 3). Using such an approach in our case would correctly identify the tumor as a likely parotid RCC metastasis. Although it remains untested here, it would be interesting to apply this algorithm prospectively to determine its effectiveness in classifying salivary gland clear cell lesions.

In conclusion, although RCC is a rare metastatic tumor of the parotid gland, there are important clinical implications for the patient. It may alert the clinician to an undiagnosed primary renal tumor and/or more widespread metastases and, depending on the patient's symptomatology and overall clinical picture, guide the decision making regarding surgical resection. Metastatic parotid RCC can be a challenging diagnosis by FNAB; there is a high rate of inadequate sampling, and the clear cell type of RCC can mimic both primary and other metastatic clear cell neoplasms. For otherwise nondiagnostic cytologic specimens with small fragments of tumor in a cell block preparation, focused immunohistochemical and/or special staining may be essential for diagnosis.

\section{Acknowledgments}

We thank Drs. Jonathan McHugh and Judy Pang for helpful suggestions during manuscript preparation and Tina Fields, Theresa Russell, and the staffs of the Department of Pathology Immunohistochemistry Laboratory at the University of Michigan and Department of Pathology and Laboratory Medicine at the VA Ann Arbor Healthcare System for technical assistance.

\section{References}

1. Bostwick DG, Cheng L. Urologic surgical pathology. St. Louis, MO: Elsevier Mosby; 2008. 1024 p.

2. Eble JN, Sauter G, Epstein JI, Sesterhenn IA. World Health Organization classification of tumours. Pathology and genetics of tumours of the urinary system and male genital organs. Lyon: IARC Press; 2004. 359 p.

3. Patey DH, Thackray AC, Keeling DH. Malignant disease of the parotid. Br J Cancer 1965;19:712-737.

4. Kucan JO, Frank DH, Robson MC. Tumours metastatic to the parotid gland. Br J Plast Surg 1981;34:299-301.

5. Percival RC, Curt JR. Metastatic hypernephroma of the parotid gland. Postgrad Med J 1982;58:167-168.

6. Sist TC, Jr, Marchetta FC, Milley PC. Renal cell carcinoma presenting as a primary parotid gland tumor. Oral Surg Oral Med Oral Pathol 1982;53:499-502.

7. Smits JG, Slootweg PJ. Renal cell carcinoma with metastasis to the submandibular and parotid glands. A case report. J Maxillofac Surg 1984;12:235-236.

8. Hessan H, Strauss M, Sharkey FE. Urogenital tract carcinoma metastatic to the head and neck. Laryngoscope 1986;96:1352-1356.

9. Harrison DJ, McLaren K, Tennant W. A clear cell tumour of the parotid. J Laryngol Otol 1987;101:633-635.

10. Gunbay MU, Ceryan K, Kupelioglu AA. Metastatic renal carcinoma to the parotid gland. J Laryngol Otol 1989;103:417-418.

11. Melnick SJ, Amazon K, Dembrow V. Metastatic renal cell carcinoma presenting as a parotid tumor: a case report with immunohistochemical findings and a review of the literature. Hum Pathol 1989;20:195-197.

12. Owens RM, Friedman CD, Becker SP. Renal cell carcinoma with metastasis to the parotid gland: case reports and review of the literature. Head Neck 1989;11:174-178.

13. Coppa GF, Oszczakiewicz M. Parotid gland metastasis from renal carcinoma. Int Surg 1990;75:198-202.

14. Pisani P, Angeli G, Krengli M, Pia F. Renal carcinoma metastasis to the parotid gland. J Laryngol Otol 1990;104:352-354.

15. Sarangi PP, Hameed B. Bilateral parotid gland metastases from a hypernephroma. J R Coll Surg Edinb 1991;36:128.

16. Ravi R, Tongaonkar HB, Kulkarni JN, Kamat MR. Synchronous bilateral parotid metastases from renal cell carcinoma. A case report. Indian J Cancer 1992;29:40-42.

17. Borghi L, Bianchini E, Ballotta MR, Reale D. Metastatic renal cell carcinoma presenting as a parotid tumor: a case report. Pathologica 1995;87:168-170.

18. Stanley MW, Bardales RH, Farmer CE, Frierson HF, Jr, Suhrland M, Powers CN, Rollins SD. Primary and metastatic high-grade carcinomas of the salivary glands: a cytologichistologic correlation study of twenty cases. Diagn Cytopathol 1995; 13:37-43.

19. Sykes TC, Patel A, Archer D, Fisher C, Hendry WF. Parotid metastasis from renal cell carcinoma. Br J Urol 1995;76:398-399.

20. Gangopadhyay K, Abuzeid MO, Martin JM, Saleem M. Metastatic renal cell carcinoma of the parotid gland presenting as a neck mass. Int J Clin Pract 1998;52:196-198.

21. Vara A, Madrigal B, Perez del Rio MJ, Diaz A, Mateos A, Sales C. Parotid metastasis from renal clear cell adenocarcinoma. An unusual site for metastasis. Urol Int 1998;61:196-198.

22. Adil G, Murat D, Ayhan O, Ozgur TM, Ibrahim Y, Fuat PA, Rifki F. Renal cell carcinoma metastasis to the parotid gland. BJU Int 1999;83:861-862.

23. Kundu S, Eynon-Lewis NJ, Radcliffe GJ. Extensive metastatic renal cell carcinoma presenting as facial nerve palsy. J Laryngol Otol 2001;115:488-490.

24. Li L, Friedrich RE, Schmelzle R, Donath K. Metachronous bilateral metastases of renal cell carcinoma to the parotid region. J Oral Maxillofac Surg 2001;59:434-438.

25. Park YW, Hlivko TJ. Parotid gland metastasis from renal cell carcinoma. Laryngoscope 2002;112:453-456. 
26. Gogus C, Kilic O, Tulunay O, Beduk Y. Solitary metastasis of renal cell carcinoma to the parotid gland 10 years after radical nephrectomy. Int J Urol 2004;11:894-896.

27. Seijas BP, Franco FL, Sastre RM, Garcia AA, Lopez-Cedrun Cembranos JL. Metastatic renal cell carcinoma presenting as a parotid tumor. Oral Surg Oral Med Oral Pathol Oral Radiol Endod 2005;99:554-557.

28. Newton JR, O'Donnell M, Samuel PR. A case of renal cell carcinoma metastasizing to the parotid gland. Otolaryngol Head Neck Surg 2007;136(4 Suppl):S65-S67.

29. Mrena R, Leivo I, Passador-Santos F, Hagstrom J, Makitie AA. Histopathological findings in parotid gland metastases from renal cell carcinoma. Eur Arch Otorhinolaryngol 2008;265:1005-1009.

30. Spreafico R, Nicoletti G, Ferrario F, Scanziani R, Grasso M. Parotid metastasis from renal cell carcinoma: a case report and review of the literature. Acta Otorhinolaryngol Ital 2008;28:266268.

31. Laco J, Celakovsky P, Kalfert D, Hornychova H, Rybnikar T, Ryska A. Tumor-to-tumor metastasis: Warthin tumor as a recipient of lung carcinoma and of renal carcinoma-report of two cases. Pathol Res Pract 2010;206:458-462.

32. Deeb R, Zhang Z, Ghanem T. Metastatic renal cell carcinoma to the parotid gland in the setting of chronic lymphocytic leukemia. Case Rep Med 2012;2012:265708.

33. Lau SY, Chittleborough TJ, McCracken JA, Wijeratne S. Metastatic clear-cell renal carcinoma to the parotid. ANZ J Surg 2012;82:760-761.

34. Gnepp DR. Diagnostic surgical pathology of the head and neck. Philadelphia: Elsevier Saunders; 2009. 1205 p.

35. Boccato $\mathrm{P}$, Altavilla G, Blandamura $\mathrm{S}$. Fine needle aspiration biopsy of salivary gland lesions. A reappraisal of pitfalls and problems. Acta Cytol 1998;42:888-898.
36. Edge SB; American Joint Committee on Cancer. AJCC cancer staging manual. New York: Springer; 2010. 648 p.

37. Bibbo M, Wilbur D. Comprehensive cytopathology. Philadelphia: Elsevier Saunders; 2008. 1120 p.

38. Cibas ES, Ducatman BS. Cytology: diagnostic principles and clinical correlates. Philadelphia: Saunders Elsevier; 2009. 537 p.

39. Prasad AR, Savera AT, Gown AM, Zarbo RJ. The myoepithelial immunophenotype in 135 benign and malignant salivary gland tumors other than pleomorphic adenoma. Arch Pathol Lab Med 1999;123:801-806.

40. de Araujo VC, de Sousa SO, Carvalho YR, de Araujo NS. Application of immunohistochemistry to the diagnosis of salivary gland tumors. Appl Immunohistochem Mol Morphol 2000;8:195-202.

41. McHugh JB, Hoschar AP, Dvorakova M, Parwani AV, Barnes EL, Seethala RR. p63 immunohistochemistry differentiates salivary gland oncocytoma and oncocytic carcinoma from metastatic renal cell carcinoma. Head Neck Pathol 2007;1:123-131.

42. Meer S, Altini M. CK7+/CK20- immunoexpression profile is typical of salivary gland neoplasia. Histopathology 2007;51:26-32.

43. Dabbs DJ. Diagnostic immunohistochemistry. Philadelphia: Elsevier Saunders; 2010. p 941.

44. Sams RN, Gnepp DR. P63 expression can be used in differential diagnosis of salivary gland acinic cell and mucoepidermoid carcinomas. Head Neck Pathol 2013;7:64-68.

45. Chenevert J, Duvvuri U, Chiosea S, et al. DOG1: a novel marker of salivary acinar and intercalated duct differentiation. Mod Pathol 2012;25:919-929.

46. O'Sullivan-Mejia ED, Massey HD, Faquin WC, Powers CN. Hyalinizing clear cell carcinoma: report of eight cases and a review of literature. Head Neck Pathol 2009;3:179-185. 